\title{
The Generation of Curiosity and New Art Style
}

\author{
Ying $\mathrm{Xu}$ \\ Zhuhai College of Jilin University \\ Zhuhai, China
}

\begin{abstract}
Curiosity is very valuable. It is the activator of creative thinking. Under the drive of curiosity, artists could fly their imaginary dreams, break the rules and create new art styles. The paper has expounded the concepts and importance of curiosity and new art styles, and stressed the importance of imagination and curiosity on the generation of new art style by discussing the three relationships of curiosity, imagination and new art style.
\end{abstract}

Keywords-curiosity; imagination; new art style

\section{INTRODUCTION}

Throughout the development history of western art: from the renaissance in fifteenth and sixteenth century, romanticism in eighteenth century, impressionism in nineteenth century to expressionism in twentieth century, every new art style forms driven by the consciousness of artists' discontent and desire to breakthrough. The discontent and desire to breakthrough require that artists have the curiosity of finding new things. The curiosity is a perceptual action; as a kind of human nature, it urges people to find new things and solve new problems. Driven constantly by consciousness and the knowledge in certain aspects, further progress can be achieved so as to create new things. In the field of art, every appearance of new art styles is contributed by the artists' constant exploration, who are unsatisfied with the reality, hoping to overturn old thoughts and modes, and strive to explore new methods including viewing angles, understanding modes, technology innovation, drawing methods and so on. Curiosity is the original impetus of the creation of new art styles.

\section{VALUABLE CURIOSITY}

Chinese eudemonics believes that human nature is not satisfied. Curiosity is the dissatisfactory psychology of people who want to know more or understand more things. Human nature is not satisfied, and the ultimate pursuit of man is happiness. Curiosity is one's desire for knowledge of some sort. It is a manifestation of one's dissatisfaction. With curiosity, people desire to know and understand the truth of things in order to get certain satisfaction and happiness. As a behavior tendency, curiosity is defined as a psychological motivation or internal motivation of individuals to react to something new or unknown. It is a behavior tendency of individual to actively explore new or unknown things, which is a multi-dimensional structure with the psychological characteristics of reactivity, initiative and persistence. Curiosity is one of the important psychological qualities of individual. It is a dynamic factor for children to know things with stable attention. It is also the precursor of interest and thirst for knowledge. [1] Anyone with achievements has a strong curiosity from childhood. Because of the drive of curiosity, they achieve success step by step. Famous scientists have curiosity. Newton became curious about an apple, and discovered gravity. Watt was very curious about the steam coming from the kettle, and finally improved the steam engine. Autistic Einstein liked playing compass in his childhood, and had a strong curiosity on it. Galileo was curious about the shaking droplight and found the simple pendulum. It can be said that curiosity is the first strong spark in the process of scientific exploration. And this spark opened the door of human wisdom. Children are more curious than adults. Children's attention is scattered, variable and jumping, so they always remain curious and fresh to unfamiliar things. We can see children combine irrelevant things together in the painting. For example, in their painting the fish can fly in the heaven; the trees can be planted to the roof; cows and dogs have wings; a person may have two long legs without body. The fabrication and imagination of children are the birthplace of fairyland. They have bees in the head and scrawl. Painter Henry Matisse said: ''look' is a creative cause, which demands effort. What we can see in our daily lives is distorted by our custom more or less". To get rid of the secular "needs courage. The courage that one sees all things as if he/she first sees is essential. We need to see the world like a child, for the loss of this visual power means the loss of originality at the same time. For example, I believe nothing is so difficult for an artist to paint a rose, because he/she shall forget all roses he/she has painted previously and create". [2] French Painter Corot said: "every day I pray my creator to change me like a child. In other words, I ask him help me to see and observe the nature like a child without any prejudice".

\section{NEW ART STYLES}

New art style refers to the unique expression way that artists create, and this expression is the original without peer. It has individual distinct characteristics. This creation comes from the individual life experience. It is a unique reflection on artistic expression. The artists dare to use new themes to create a new aesthetic thought, and have the ability to create an effective way to expression this unique conception in new form and show the positive meaning of this expression way in art. The new art style, in the ways of expression, must be a new and fancy style. It boldly surpasses the frame of "right" and "wrong", and creates something original and new. It has an unimaginable and attractive character. Even it brings great shock to mind. You cannot help but wonder some people 
unexpectedly think and express art from such a perspective. Cezanne first used flat brushwork to paint. According to the classic painting theory, it is "wrong", because it causes obvious "defect" that the painting seems to be uncompleted. The Western classical painting emphasizes exquisite techniques, and pursues complete and sound expression. It would be best if there is no independent brushwork that shows the separation between object and image. The flat brushwork of Cezanne leaves people a sloppy expression. According to the classical aesthetic theories, his paintings with brushwork and the separation of object and image were crudely made without culture, and totally inconsistent with the performance principle of the art of painting. Even he was like a junior scholar, and was derided as "the smelly pit of the country" at that time. But because of this, Cezanne created a new art style. Picasso, at the age of sixteen, was able to paint a very good realistic painting. But he did not stick to the traditional painting expression. Uncharacteristically, he moved towards an unimaginable expression direction - the cubism with picture of constitutive character. Picasso saw some special performance and formative characteristics from the African sculpture, and thus gave up his realistic painting method. He applied this expression technique into his works, and started a new situation in the cubism painting. The revolutionary exploration and expression of Picasso in painting has changed the traditional concept of art, making him play the leading role in the history of modern art. His influence is enduring and lasting.

\section{CURIOSITY AND NEW ART STYLE}

\section{A. Curiosity Drives Imagination}

Curiosity is the possibility of loving novel information. Curiosity is to measure the possibility degree of display of novel information in one's mind. The stronger the curiosity is, the higher the possibility degree of display of novelty information is in the brain. In the face of new problems, if known information and methods cannot be used to solve the current problems, curiosity will take the initiative to expand outwards, and drive people to explore new information to establish contact with other information, or change according to other modes. Curiosity is the basic control factor of introducing novel information into psychological space. [3] At the same time curiosity can effectively expand the imagination of space. The stronger the curiosity is, the greater the universal set is, and the more dispersed the possibility degree of elements in universal set is, and the more uncertain the meaning is. Curiosity promotes imagination and makes the brain more open. The more contradictory the relational information is, and it is related to the problem, the more powerfully it can stimulate the mentality of people. If it forms certain significance through coordination, they can produce more powerful fusion variability. The psychology to pursue novelty and imagination makes the brain more open. The opening of brain is regarded as self-affirmation psychology in the process of imagination, and it will show a more open attitude in later performance, and become the state of active pursuit. Curiosity makes imagination more changeable, so that it can avoid the psychological conversion process falling "local stability" of certain meaning, and avoid premature convergence of mental processes. The exploration produced by curiosity makes imagination more novel, and keeps imagination go forward by avoiding the psychological conversion process falling into "local minima". Curiosity is man's instinct, and imagination is also man's instinct. These instincts are more pronounced in infancy. Curiosity encourages imagination to expand, and imagination also satisfies curiosity. They are mutually complementary, and constitute a stable correspondence. But curiosity constantly introduces novel information into psychological space, prompting the formation and identification of the whole meaning of novelty. Therefore, curiosity is the most basic promoting force for imagination.

\section{B. The Generation of Artistic New Style Needs Wings of Imagination}

Hagel once said: in the process of artistic creation, "if it comes to abilities, the most outstanding artistic ability is imagination." This fully illustrates the importance of imagination for art. Works without imagination is the reproduction of reality. Artistic works with imagination is higher than reality, higher than life. It is the fit of reality and spirit. Innovation needs the support of imagination, the reality needs imagination to make breakthrough. Especially for art, no matter artistic creation or artistic appreciation, the role of imagination cannot be replaced. The essence of art lies in touching the most essential things of life and giving aesthetic salvation. Imagination is the most important means to strengthen the essence of art. Imagination is the important reason why art becomes art. In the art aesthetic realm of imagination, the most important role of imagination is to develop a sky for the freedom of human spirit. Dali is an imaginative painter. He presented the subjective world in his dream on the picture. In his paintings ordinary images were distorted, deformed and illogically placed in an unreasonable fantastic dream way to constitute a realm of subconscious illusion. The painter elaborately depicted images and details of the picture with surreal skill, which brings viewers into a bizarre surrealism world. His imagination and creativity are amazing. Because of his imagination he established the Surrealism. The works of Spanish Painter Miro surpassed realism. He found the childlike innocence of life, abandoned the poker-faced face of civilization, and returned to naturally primitive life. With childlike innocence and imagination, he exchanged with the earth, the Milky Way, birds and animals. His creations present us a new and free world, and bring us in the palace of the imagination.

\section{CONCLUSION}

Curiosity is valuable. It is the activator of creative thinking. It makes artists interested in all creatures of the world, and encourages them to observe, think and practice. Under the drive of curiosity, imagination constantly expands and fully free artists' mind and fly their dreams in the artistic sky. New art style cannot be separated from valuable curiosity and inseparable from the rich imagination.

\section{REFERENCES}

[1] $\mathrm{Xu}$ Yuchun. Curiosity and Imagination. 78. 
[2] Zong Baihua. Aesthetic Literary Selections of Zong Baihua's Translation. Peking University Press, 239.

[3] Xu Chunyu. Curiosity and Imagination. 238. 